UCRL-ID-119535-2

\title{
Progress Reports for Period December 1-31, 1994 Joint UK/US Radar Program
}

\author{
R. E. Twogood \\ J. M. Brase \\ D. D. Mantrom \\ C. Rino \\ D. H. Chambers \\ H. F. Robey \\ J. Belyea
}

January 23, 1995

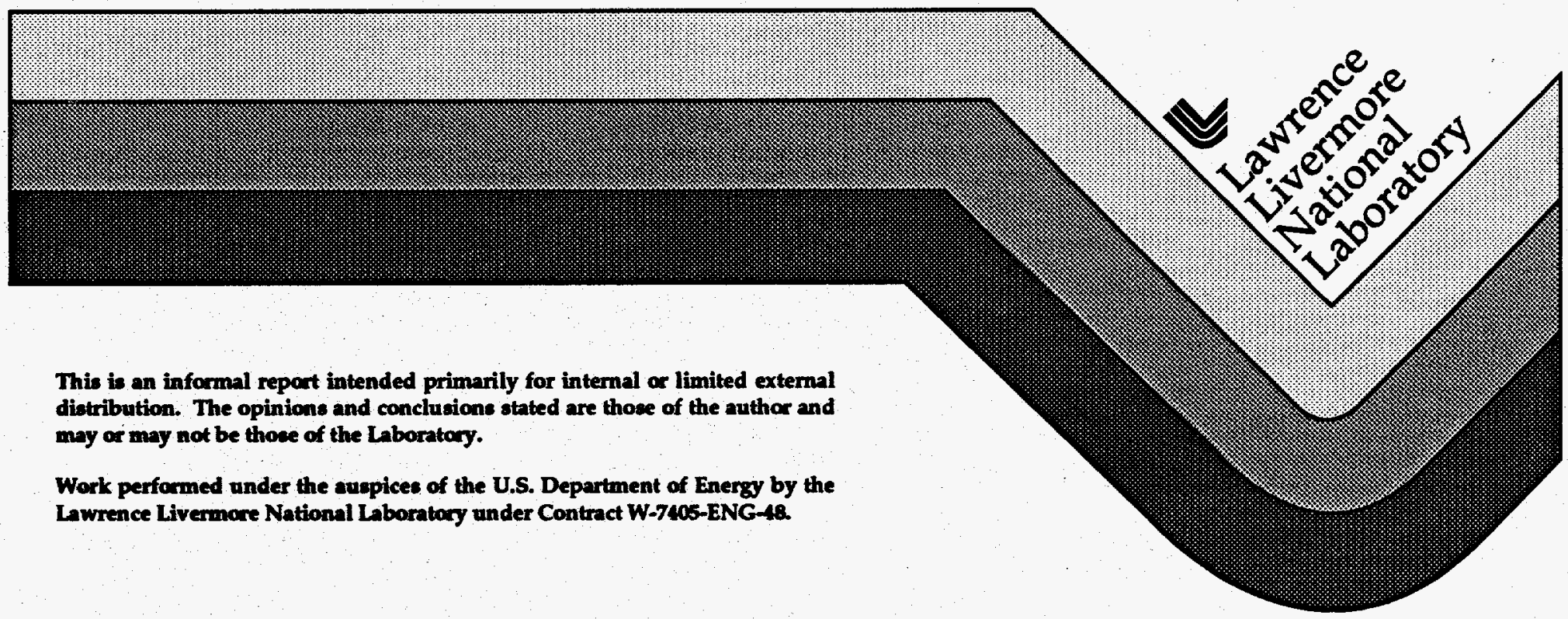




\section{DISCLAMER}

This document was prepared es an cocount of work sponsored by an agency of the United States Government. Neither the United States Covernment nor the University of California nor any of their employees, makes any warranty, express or implied, or asumes any legal liability or responsibility for the accuracy, completeness, or usefulness of any information, apparatus, product, or process disclosed, or represents that its use would not infringe privately owned rights. Reference herein to any specific commercial product, process, or service by trade name, trademark, manufacturer, or otherwise, does not necesearily constitute or imply its endorsement, recommendation, or favoring by the United States Government or the University of California. The views and opinions of authors expressed herein do not necesearily state or reflect those of the United States Covernment or the University of California, and shall not be used for edvertising or product endorsement purposes.

This report has been reproduced directly from the best available copy.

Available to DOE and DOE contractors from the Office of Scientific and Technical Information

P.O. Box 62, Oak Ridge, IN 37831

Prices available from (615) 576-8401, FTS 626-8401

Avellable to the public from the

National Technical Information Service

U.S. Department of Commerce

5285 Port Royal Rd.

Springfield, VA 22161 


\section{DISCLAIMER}

Portions of this document may be illegible in electronic image products. Images are produced from the best available original document. 
Progress Reports for period December 1-31, 1994

Joint UK/US Radar Program 1/19/95

Organization: LLNL

Program: P.LLN.1010 Airborne RAR/SAR

Principal Investigator: Richard E. Twogood

Current Objectives:

Modify Hughes $\mathbf{x}$-band radar for airborne implementation.

Upgrade to polarimetry, high-power, and add SLAR mode.

Deploy in UK/US field experiments as needed.

\section{Recent accomplishments:}

Hughes and LLNL continued work on system integration, radar hardware, and associated control hardware and software. The belly radome design modification has been completed.

The forebay rack has been designed, built and installed. The required DOE safety review was conducted on $12 / 8 / 94$, with no new issues raised.

The overall radar and testbed is now scheduled for engineering checkout in April 1995, pending the arrival of FY95 funds as expected.

Milestones for the reporting period:

No major milestones scheduled for December.

Expected milestones for the ensuing period:

April 1995 Engineering Checkout(s)

June 1995 First experimental deployment

\section{Other Issues:}

None

Planned expenditures versus actuals:

FY95 Budget Plan: $\quad \$ 1500 \mathrm{~K}$

December 94 costs: $\quad \$ 56 \mathrm{~K}$

Year-to-date costs: $\quad \$ 164.1 \mathrm{~K}$ 
Organization: LLNL

Program: P.LLN.1020 Radar Data Processor

Principal Investigator: James M. Brase

Current Objectives:

Integration and test of the real-time SAR processor for the Hughes airborne radar; define and develop the SAR Doppler and related analysis software for this unique system; develop the similar system for the UK testbed (OITB)

\section{Recent accomplishments:}

The radar data processor computer hardware has all been successfully integrated. The baseline SAR processor is complete and successfully tested. Work began on integration of the high-speed disk arrays.

\section{Milestones for the reporting period:}

Completed baseline SAR processor testing.

Expected milestones for the ensuing period:

Integration of disk array by February ' 95.

Start high-speed tape drive integration February '95.

Full-speed operation demo by March ' 95 .

\section{Other Issues:}

None.

Planned expenditures versus actuals:

FY95 Budget Plan:

December 94 costs:

$\$ 750 \mathrm{~K}$

Year-to-date costs:

$\$ 46.3 \mathrm{~K}$

$\$ 248.5 \mathrm{~K}$ 
Organization: LLNL

Program: P.LLN.1030 Ground-based SAR Signal Processing Workstation

Principal Investigator: James M. Brase

Current Objectives:

Develop capabilities for motion compensation and autofocus for Hughes SAR and UK system. Enhance SAR processors with multi-look software. Analyze the low-grazing angle (LGA) processing steps and improve performance of LGA processing.

\section{Recent accomplishments:}

$2 x$ speed-up of LGA processing software by optimization of Doppler filtering. Developed preliminary 2D approach to precision motion compensation for SAR. Report is in preparation. Began work on incorporation of non-linear filters into LGA processing.

Milestones for the reporting period:

Completed work on LGA processing with $2 x$ speed-up

Expected milestones for the ensuing period:

Report on precision SAR processing approach in February '95.

Software requirements document for precision SAR processor in February ' 95.

Initial release of precision SAR processor (motion compensation and auto focus) in March '95.

Other Issues:

None.

Planned expenditures versus actuals:

FY95 Budget Plan: $\quad$ \$750K

December 94 costs: $\quad \$ 32.5 \mathrm{~K}$

Year-to-date costs: $\quad \$ 88.4 \mathrm{~K}$ 
Organization: LLNL

Program: P.LLN.1040 Static Airborne Radar

Principal Investigator: Richard E. Twogood

Current Objectives:

Procure GFE excess equipment including aerostats, platforms, and ancillary systems. Perform checkout of hardware. Assess options for stabilized realaperture radar experiments using these aerostats systems. FY95 funding permitting, include these systems in radar experiments beginning in summer 1995.

\section{Recent accomplishments:}

We continued the systems check-out for aerostats, mooring platforms and support hardware. The baseline system using the LLNL platform obtained from Beaumont, TX has been designed. Implementation awaits FY95 funding.

Milestones for the reporting period:

Preliminary design/analysis of Beaumont system completed.

Expected milestones for the ensuing period:

Determine issues and costs for IR support at October 95 Autec test. Initial radar system checkout and experiments, June 1995.

\section{Other Issues:}

The UK has indicated providing an aerostat for Autec in October is a high priority. IR systems would be deployed (presumably the existing ERIM sensors already successfully used, but they would need to be fitted to the aerostat). The existing budget for this task will be insufficient for both objectives (radar support for COPE and IR support for Autec). At this point it appears slippage of the radar support is most likely unless additional funds for IR support are available through the IR tasks. Decision needs to be made (by February '95), with UK input, regarding October test.

\section{Planned expenditures versus actuals:}

FY95 Budget Plan: . \$1000K

December 94 costs: $\quad \$ 36.7 \mathrm{~K}$

Year-to-date costs: $\quad \$ 117 \mathrm{~K}$ 
Organization: LLNL

Program: P.LLN.1050 Multi-Aperture Space-Time Array Radar

Principal Investigator: James M. Brase

Current Objectives:

Perform feasibility study and preliminary design of a multi-aperture radar for high resolution, in both range and azimuth, imaging of the ocean surface.

Recent accomplishments:

Discussion with $\mathrm{K}$. Ward postponed until his March visit.

Milestones for the reporting period:

None.

Expected milestones for the ensuing period:

Initiation of project in February '95; preliminary discussion with Keith Ward in March ' 95.

\section{Other Issues:}

None.

Planned expenditures versus actuals:

FY95 Budget Plan: $\quad$ \$200K

December 94 costs: \$OK

Year-to-date costs: $\quad \$ 0 \mathrm{~K}$ 
Organization: LLNL

Program: P.LLN.1060 Radar Field Experiments

Principal Investigator: David Mantrom

Current Objectives:

Complete analysis of Loch Linnhe 1994 data. Plan and prepare for 1995 experiments.

Recent accomplishments:

Continued analysis of density stratification/shear profile data from Loch

Linnhe. The emphasis is on the effect of cross-track shear on the kinematics of the internal wave wake patterns observed by the radars. Continued analysis of historical density profiles for the vicinity of the COPE trial in Sept. 1995. A report is in preparation. Test Description documents for a summer AUTEC detection test and/or COPE (Oregon experiment in collaboration with NOAA/ETL) have been written (but not transmitted).

We have cancelled plans for a major July 1995 detection experiment at AUTEC. We have kept open an option for flights over targets of opportunity. We have also kept open an option for a limited participation in COPE. Communications have remained open with AUTEC and NOAA/ETL for the purpose of planning 1995 experiments.

\section{Milestones for the reporting period:}

None.

Expected milestones for the ensuing period:

We will integrate requirements for ocean clutter data collection with the AETB/SAR into its engineering flights.

A report on the density profiles and dispersion relations for the vicinity of the COPE trial should be completed in January.

A report on the effect of shear on ship internal wave patterns is in progress. Expected completion in 1-2 months.

\section{Other Issues:}

None.

Planned expenditures versus actuals:

FY95 Budget Plan: \$2000K

December 94 costs: $\quad \$ 62.5 \mathrm{~K}$

Year-to-date costs: $\quad \$ 368 \mathrm{~K}$ 
Organization: LLNL

Program: P.LLN.1070 Data Analysis and Detection Theory

Principal Investigator: James M. Brase

Current Objectives:

Complete baseline analysis of Loch Linnhe data.

Complete report on MTF for LGA data (1989-94 data sets).

Continue Doppler analysis and detection implications.

Analysis of UCSB data as it comes in.

Recent accomplishments:

Quick-look reports on Loch Linnhe 94 have been completed and distributed. Detailed Doppler analysis of LL-94 data continues.

Analysis of effects of non-linear filters on LGA imagery begun.

Milestones for the reporting period:

LL-94 quick-look reports completed.

Expected milestones for the ensuing period:

Initial report on effects of non-linear filters in January ' 95.

Report on November ship wake meeting in January '95.

Parametric study of LGA image quality for 1989-94 database in February ' 95.

Full analysis reports for LL-94 in March '95.

Other Issues:

None.

Planned expenditures versus actuals:

FY95 Budget Plan:

December 94 costs:

$\$ 700 \mathrm{~K}$

Year-to-date costs:

$\$ 97.5 \mathrm{~K}$

$\$ 372 K$ 
Organization: LLNL

Program: P.LLN.1080 Management

Principal Investigator: Richard E. Twogood

Current Objectives:

Provide ongoing management oversight and support for the Joint UK/US Radar Program (Twogood) and staff support in Washington for the ASAP program office (Thomson, Hutchins, Chocol), in addition to other consultant and management services (Wells, Manasse, etc.). All administrative support for UK/US program included.

\section{Recent accomplishments:}

Coordination of future meetings and new initiatives was performed. Continued full-time support of ISSO Ballston office by Thomson, Hutchins, and Chocol.

Management oriented meeting was held at UCSB on 12/13-14 with concurrence achieved on logistics issues with multiple organizations involved. Preliminary field experiments planning meeting, with UK attendance, held at LLNL 12/2/94.

Milestones for the reporting period:

Field experiments planning meeting at LLNL 12/2/94.

UCSB planning meeting 12/12-13.

\section{Expected milestones for the ensuing period:}

Ongoing support to ISSO office by program office staff.

Other Issues:

None.

Planned expenditures versus actuals:

FY95 Budget Plan: $\quad \$ 1000 \mathrm{~K}$

December 94 costs: $\quad \$ 376 \mathrm{~K}$

Year-to-date costs: $\quad \$ 891.4 \mathrm{~K}$ (includes accruals of overruns from FY94) 
Organization: LLNL

Program: P.LLN.1090 E-2C Radar Data Analysis

Principal Investigator: Charles Rino

Inputs to be provided separately to ISSO directly by Vista Research. 
Organization: LLNL

Program: P.LLN.1110 Modeling and Analysis (LLNL)

Principal Investigator: David Chambers

Current Objectives:

Analysis of Loch Linnhe 1994 hydrodynamics data.

Development of turbulent wake model.

Estimate wind-wave relaxation times.

\section{Recent accomplishments:}

Continued analysis of Loch Linnhe hydro data. Completed first version of turbulent wake model, began comparison with IAP wave tank data.

\section{Milestones for the reporting period:}

Completed first version of turbulent wake model.

Expected milestones for the ensuing period:

Documentation of hydro analysis for Loch Linnhe by January 1995.

Complete turbulent wake source model upgrade and continue comparison with IAP wave tank data.

Simulate Stokes wave forced by wind and follow to breaking.

\section{Qther Issues:}

None.

\section{Planned expenditures versus actuals:}

FY95 Budget Plan:

$\$ 330 \mathrm{~K}$

December 94 costs:

$\$ 16.7 \mathrm{~K}$

Year-to-date costs:

$\$ 48.0 \mathrm{~K}$ 
Organization: LLNL

Program: ·.LLN.1150 Modeling and Analysis (Vista)

Inputs to be provided to ISSO directly by Vista Research. 
Organization: LLNL

Program: P.LLN.1170 Current Meter Array

Principal Investigator: David Mantrom

\section{Current Objectives:}

Loch Linnhe 1994 CMA data analysis and documentation.

Upgrades to power system, structure, and data acquisition for future tests.

\section{Recent accomplishments:}

We have continued our analysis of LL94 CMA data. We received GPS position data for the CMA and the target ships. About $1 / 2$ of the ship track data and 1/4 of the CMA position data is usable. Results indicate that the ships passed about $25 \mathrm{~m}$ closer to the CMA than the nominal distances. Ship heading and CMA orientations are slightly different than the nominal, but are consistent from run-to-run. We are making a direct effort to understand why ship-generated IW's were seen by the CMA in some records and not in others. We are looking at operating and environmental effects on IW generation and ambient noise levels. Preliminary results from applying noise rejection algorithms to the ship wake data show little benefit from one such algorithm. We are in the process of formulating a different approach.

We have put aside upgrades to the CMA pending resolution of uncertainties involving future field experiments.

\section{Milestones for the reporting period:}

None.

Expected milestones for the ensuing period:

Completion of data analysis with noise rejection algorithm \#1.

List of upgrade requirements for 1995 CMA deployment(s).

\section{Other Issues:}

None.

Planned expenditures versus actuals:

FY95 Budget Plan:

December 94 costs:

Year-to-date costs:
$\$ 300 \mathrm{~K}$

$\$ 17.5 \mathrm{~K}$

$\$ 17.5 \mathrm{~K}$ 
Organization: LLNL

Program: P.LLN.1410 UCSB Wave Tank

Principal Investigator: Harry Robey

Current Objectives:

Continue hydro measurements program at UCSB.

Install radars in tank: initially UCSB's C-band and LLNL's existing wideband; later TRW's x-band.

Recent accomplishments:

Work continued on the radar systems to be deployed at the UCSB tank. The UCSB linear FM radar (5-8 Ghz) is operating; initial analysis of the data shows the radar is working as hoped. The LLNL impulse radar $(1-3 \mathrm{Ghz})$ is operational and back at LLNL. It will return to UCSB in February 95 pending scheduling meetings with UCSB. The TRW radar ( $10 \mathrm{Ghz})$ is expected to be ready in January 1995.

A planning meeting for coordinating the UCSB and LLNL work at UCSB was held on December 12-13, 1994. Plans for coordination among groups, data management, and publications were discussed.

Milestones for the reporting period:

Planning meeting at UCSB coordinating UCSB, LLNL and DRA Malvern activities.

Expected milestones for the ensuing period:

Installation of LLNL wideband system (on more or less permanent basis) 2/95.

Other Issues:

None.

Planned expenditures versus actuals:

FY95 Budget Plan: $\quad \$ 800 \mathrm{~K}$

December 94 costs: $\quad \$ 77.6 \mathrm{~K}$

Year-to-date costs: $\quad \$ 142.9 \mathrm{~K}$ 
Organization: LLNL

Program: P.LLN.1420 Stratified Flow Facility

Principal Investigator: Harry Robey

Current Objectives:

Re-start experiments on internal wave generation by a turbulent wake in enlarged test section.

Recent accomplishments:

Received quote on the upgrade to the Stratified Flow Facility (to more than double the available test section length) from Engineering Laboratory Design (ELD). The cost for the upgrade is $\$ 48.3 \mathrm{~K}$. Further action is on hold pending funding.

Milestones for the reporting period:

None.

Expected milestones for the ensuing period:

Further action is on hold pending funding.

Other Issues:

None.

Planned expenditures versus actuals:

FY95 Budget Plan:

December 94 costs:

$\$ 200 \mathrm{~K}$

Year-to-date costs:

$\$ 22.7 \mathrm{~K}$

$\$ 42.0 \mathrm{~K}$ 
Organization: LLNL

Program: P.LLN.1430 Institute of Applied Physics, Russia

Principal Investigator: Harry Robey

\section{Current Objectives:}

Conduct wave tank studies in the thermally stratified tank at IAP in Russia. Current emphasis is on a continuation of experiments on internal wave generation by a towed body and its turbulent wake. Also, previous results will be extended to include the effects of shear.

\section{Recent accomplishments:}

The new contract is in place, and work is underway on phase one of the experiments. This first phase will repeat the experiments using a towed sphere in a thermocline and will address the statistical repeatability of the results previously obtained and documented in Report 3 (Study of Internal Waves Generated by a Moving Body, IAP, 1994).

\section{Milestones for the reporting period:}

New contract is in place.

Expected milestones for the ensuing period:

Report 1 covering the first phase of the work will be delivered in three months from placement of the contract.

\section{Other Issues:}

None.

Planned expenditures versus actuals:

FY95 Budget Plan: \$350K

November 94 costs: $\quad \$ 0 \mathrm{~K}$

Year-to-date costs: $\quad \$ 0 \mathrm{~K}$ 
Organization: LLNL

Program: P.LLN.1210 IR Sensor Systems

Principal Investigator: Jerry Belyea

Inputs to be provided to ISSO directly by ERIM. 


\section{Budget Status}

Budget breakdown by individual ISSO work assignment are described in the above individual work unit assignments. Overall UK/US Radar Program funding status is as follows (includes all LLNL costs, involving work unit):

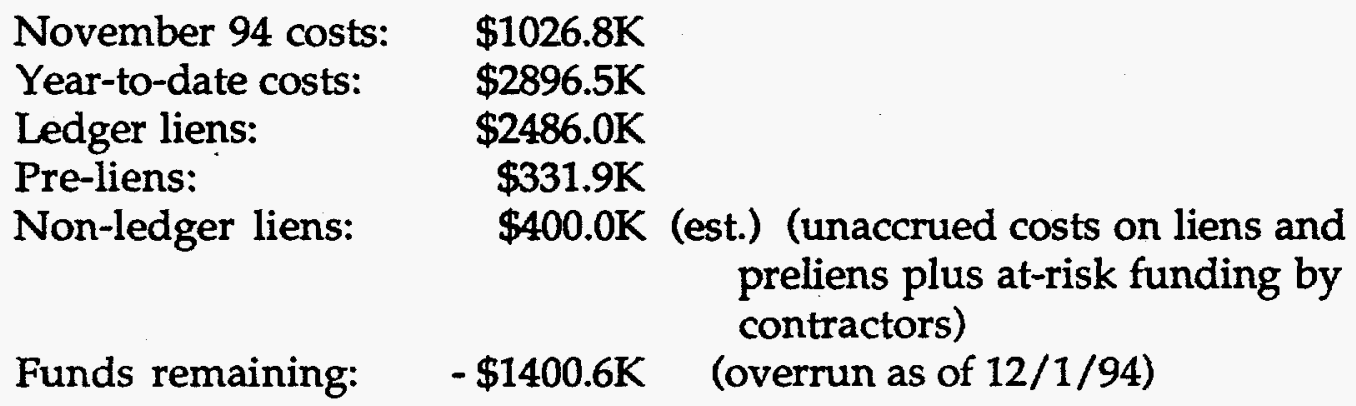

Funds remaining: $\quad-\$ 1400.6 \mathrm{~K} \quad$ (overrun as of $12 / 1 / 94$ )

Discussion of funding: ISSO has processed the MIPR to address the above overrun. Steps that were underway to stop UK/US program activities and stop work at contractors have been delayed due to action taken by the Director of ISSO to get funding released to LLNL. 